\title{
Vitamin D and its metabolites inhibit cell proliferation in human rectal mucosa and a colon
} cancer cell line

\author{
M G Thomas, S Tebbutt, R C N Williamson
}

\begin{abstract}
Like calcium, vitamin D may protect against colorectal neoplasia as it reduces epithelial cell proliferation and induces differentiation. Although its therapeutic use is limited by its effects on calcium metabolism, analogues such as calcipotriol produce little hypercalcaemia. Stathmokinetic and immunohistochemical techniques were used to study the effect of $1,25(\mathrm{OH})_{2} \mathrm{D}_{3}$ and its analogues on cell proliferation in human rectal mucosa and a colon cancer cell line. Paired sigmoidoscopic biopsy specimens were obtained from 17 control patients and five patients with familial adenomatous polyposis. Explants were established in organ culture, with or without the addition of vitamin D. Proliferation was assessed using (1) metaphase arrest to determine the crypt cell production rate (CCPR) and (2) $\mathrm{Ki}$-67 monoclonal antibody directed against an antigen present in proliferating cells. 1,25 $(\mathrm{OH})_{2} \mathrm{D}_{3}$ in concentrations of $1 \mu \mathrm{M}-100 \mathrm{pM}$ $\left(10^{-6}-10^{-10} \mathrm{M}\right)$ reduced the CCPR (cells/ crypt/hour) from 4.74 to $2 \cdot 15-2.67$ (p $<0.001$ ), and the Ki-67 labelling index from 7-28-3.74 $(\mathbf{p}<0.01)$. Likewise, vitamin $D_{2}, 10 \mathrm{nM}$ $\left(10^{-8} \mathrm{M}\right)$ reduced the CCPR from 4.74-2.74 $(p<0.05)$ and calcipotriol from $4.86-2.38$ $(p<0.05)$. In familial adenomatous polyposis patients $1,25(\mathrm{OH})_{2} \quad \mathrm{D}_{3} 100 \mathrm{pM}\left(\mathbf{1 0}^{-10} \mathrm{M}\right)$ halved the CCPR from 8.75-4.22. Calcipotriol $\left(10^{-5} \mathrm{M}\right.$ to $\left.10^{-9} \mathrm{M}\right)$ produced a clearcut dose response inhibition of HT-29 cell growth. Thus, vitamin D and its metabolites inhibit proliferation in normal and premalignant rectal epithelium and suppress growth in a colorectal cancer cell line.
\end{abstract}

(Gut 1992; 33: 1660-1663)

There is a clear link between the intensity of cell proliferation and susceptibility to neoplasia. ${ }^{12}$ In the large intestine, surgical or dietary manipulations that stimulate cell growth generally promote experimental colorectal carcinogenesis, ${ }^{3-5}$ whereas mucosal hypoplasia (for example, by defunctioning colostomy) has a protective effect. ${ }^{6}$ Patients with colonic adenoma or carcinoma show increased labelling indices in 'normal' biopsy specimens taken from multiple sites, ${ }^{7}$ and those with ulcerative proctocolitis have increased crypt cell proliferation even in quiescent disease. ${ }^{8}$ Thus, the cytokinetic status of the epithelium ${ }^{910}$ could reflect a subject's susceptibility to colorectal neoplasia.

Calcium may protect against colorectal cancer by reducing epithelial cell turnover. ${ }^{12}$ Vitamin $D$ could be another chemopreventative agent ${ }^{13}$ because of its ability to switch cellular activity (in various cancer cell lines) from proliferation to differentiation. ${ }^{1+16}$ In particular, the human colon cancer cell lines HT-291718 and LOVO ${ }^{14}$ possess high affinity receptors for the active metabolite of vitamin $\mathrm{D}_{3}\left(1,25(\mathrm{OH})_{2} \mathrm{D}_{3}\right)$, which suppresses cell growth and induces changes indicative of differentiation. Receptors for 1,25 $(\mathrm{OH})_{2} \mathrm{D}_{3}$ have also been found in normal human colon. ${ }^{19}$ Although the therapeutic use of 1,25 $(\mathrm{OH})_{2} \mathrm{D}_{3}$ and 1-alpha hydroxycholecalciferol is limited by their profound effects on calcium metabolism, ${ }^{20}$ analogues such as calcipotriol (MC-903, a secosterol) ${ }^{21-23}$ are now available which have limited hypercalcaemic and hypercalciuric effects.

We have used stathmokinetic and immunohistochemical techniques to study the effect of three agents $-1,25(\mathrm{OH})_{2} \mathrm{D}_{3}$, vitamin $\mathrm{D}_{2}$, and calcipotriol - on cell proliferation in human rectal epithelium. We have studied both macroscopically normal rectal tissue in control patients and those with familial adenomatous polyposis (at increased risk of neoplasia) and HT-29 cells in culture.

\section{Methods}

\section{RECTAL BIOPSY SPECIMENS}

Paired rectal biopsy specimens were taken from 17 patients (mean age 60 years, range 37-80 years) with macroscopically normal rectal mucosa who were attending the outpatient clinic with incidental anal conditions. Biopsy specimens were also obtained from five patients (mean age 38 years, range 35-40 years) with familial adenomatous polyposis who had previously undergone total abdominal colectomy with ileorectal anastomosis and were attending regularly for follow up. One specimen from each patient was examined histologically to exclude mucosal disease, notably microadenoma in familial adenomatous polyposis. The other biopsy specimen was maintained in organ culture with or without the addition of vitamin D metabolites. In four control patients, tissue was frozen to $-80^{\circ} \mathrm{C}$ (after organ culture) for subsequent immunohistochemistry.

Local ethical committee approval was obtained, and all patients had given fully informed consent to the procedures.

\section{VITAMIN D PREPARATIONS}

$1,25(\mathrm{OH})_{2} \quad \mathrm{D}_{3}$ and ergocalciferol (vitamin $\mathrm{D}_{2}$ ) were donated by Roche Products Ltd (Welwyn Garden City, UK). The secosterol calcipotriol 
(MC-903) was supplied by Leo Pharmaceutical Products Ltd (Ballerup, Denmark).

Stock solutions of test compounds were prepared in absolute alcohol and stored at $-20^{\circ} \mathrm{C}$ until use. Control medium was prepared with a similar dilution of alcohol and in a pilot study had no obvious effect on proliferation.

\section{ORGAN CULTURE}

Rectal biopsy specimens were divided into tiny explants and orientated mucosal surface uppermost on a metal grid within an organ culture dish (Lux Laboratories). Explants were cultured as paired samples in standard culture medium (CMRL 1066, Gibco, Paisley, UK) or in standard culture medium to which vitamin $\mathrm{D}$ metabolites had been added: $1,25(\mathrm{OH})_{2} \mathrm{D}_{3}$ at concentrations of $1 \mu \mathrm{M}\left(10^{-6} \mathrm{M}\right), 10 \mathrm{nM}\left(10^{-8}\right.$ $\mathrm{M})$, or $100 \mathrm{pM}\left(10^{-10} \mathrm{M}\right)$; ergocalciferol (vitamin $\left.\mathrm{D}_{2}\right)$ at $10 \mathrm{nM}\left(10^{-8} \mathrm{M}\right)$; and calcipotriol (MC903) at $100 \mathrm{mM}\left(10^{-7} \mathrm{M}\right)$. Thus each biopsy specimen acted as its own control. The concentrations of vitamin $\mathrm{D}$ chosen were in a similar range to previous studies, ${ }^{1+18}$ and the lowest dose of $1,25(\mathrm{OH})_{2} \mathrm{D}_{3}$ is probably within the human physiological range. In total, 34 biopsy specimens were obtained from controls and 10 from familial adenomatous polyposis patients, and each biopsy was divided into several explants (between six and 15).

The concentration of $1,25(\mathrm{OH})_{2} \mathrm{D}_{3}$ in the standard culture medium was $6 \mathrm{pM}\left(6 \times 10^{-12}\right.$ $M)$, as determined by batch testing the fetal calf serum. The organ culture dishes were sealed in an atmosphere of $95 \% \mathrm{O}_{2}$ and $5 \% \mathrm{CO}_{2}$ at a temperature of $37^{\circ} \mathrm{C}$ and were then gently rocked at 5 cycles per minute. ${ }^{24}$ After 15 hours, vincristine $0.6 \mu \mathrm{g} / \mathrm{ml}$ (Oncovin, Eli Lilly, Basingstoke, UK) was added to the culture medium to induce metaphase arrest within the colonic crypts. ${ }^{82}$ Explants were removed one, two, and three hours later, fixed in Carnoy's fluid, and stored in $70 \%$ alcohol. Biopsy tissues were rehydrated later in successive solutions of $50 \%, 25 \%$, and $10 \%$ alcohol. After acid hydrolysis in $1 \mathrm{M} \mathrm{HCl}$ at $60^{\circ} \mathrm{C}$ for 6 minutes, explants were stained with Schiff's reagent. At least 20 crypts were microdissected from each specimen, ${ }^{25}$ and the number of arrested metaphases per crypt was plotted against time from vincristine administration. The slope of this line (determined by least squares linear regression analysis) gave a value for the crypt cell production rate in cells/crypt/hour. ${ }^{11}$

\section{IMMUNOHISTOCHEMISTRY}

After 18 hours' organ culture in medium with or without the addition of $1,25(\mathrm{OH})_{2} \mathrm{D}_{3}(100 \mathrm{pM})$, paired mucosal explants were mounted and then $3 \mu \mathrm{m}$ cryostat sections were cut and air dried before blocking in $\mathrm{H}_{2} \mathrm{O}_{2}(0 \cdot 22 \%)$ and methanol for 5 minutes. After washing in tap water and then Tris buffer $(\mathrm{pH} 7 \cdot 3$ ) for 5 minutes $(\times 3)$, sections were stained using a three stage peroxidase procedure in which $\mathrm{Ki}-67$ monoclonal antibody (1:50 in Tris buffer), biotinylated rabbit anti-mouse (1:300 in Tris buffer), and avidinbiotin complex (Dakopatts) were applied. The
$\mathrm{Ki}-67$ antibody is directed against an antigen expressed in proliferating cells. ${ }^{26} 27$ Slides were developed in diamino benzadine-hydrogen peroxide (DAB) in Tris buffer for 5 minutes, then washed in tap water. Haematoxylin was used as a counterstain.

To assess rectal epithelial proliferation, the labelling index was determined in at least 15 crypts per section. ${ }^{28}$ The labelling index was calculated as the ratio of $\mathrm{Ki}-67$ positive to negative cells per crypt. The mean values of these counts were compared using a paired Student's $t$ test (each case acting as its own control).

\section{CELL CULTURE}

HT-29 cells were maintained as a monolayer of cells in Dulbecco's modified Eagle's medium (DMEM, Flow Laboratories, High Wycombe, UK) with $10 \%$ fetal calf serum, $100 \mathrm{U} / \mathrm{ml}$ penicillin, and $100 \mu \mathrm{g} / \mathrm{ml}$ streptomycin (Serolabs, Crawley, UK). Cells were incubated at $37^{\circ} \mathrm{C}$ in $95 \% \mathrm{O}_{2}$ and $5 \% \mathrm{CO}_{2}$, and the medium was changed every 2 days. At $80-90 \%$ visual confluence, the cells were trypsinised with $0.25 \%$ trypsin and EDTA (Flow Laboratories). After washing in phosphate buffer saline (PBS), aliquots of $1 \times 10^{4}$ cells were added to a six well tissue culture plate (Gibco). The cells were cultured in DMEM, with or without the addition of calcipotriol (MC-903) at a final concentration of $10^{-5}$ to $10^{-9} \mathrm{M}$. All plates were set up in quadruplicate.

After viability assessment using trypan blue exclusion, the total cell number was determined at 7,14 , and 21 days by counting at least three samples from each concentration using a haemocytometer. Results were analysed using one way analysis of variance and the Mann-Whitney U test.

\section{Results}

ORGAN CULTURE

The overall mean (SEM) crypt cell production rate (CCPR) in 17 normal patients (Figure) was $4.74(0.25)$ cells/crypt/hour, with a range of $2 \cdot 85-7 \cdot 07$. This value is similar to but slightly lower than our previously reported results. ${ }^{824}$ Explants showed excellent preservation of crypt architecture, with an infection rate and crypt necrosis rate of less than $1 \%$. The active form of vitamin $\mathrm{D}_{3}\left(1,25(\mathrm{OH})_{2} \mathrm{D}_{3}\right)$ consistently halved the overall CCPR in normal tissue irrespective of the dose used (analysis of variance). Thus, at $1 \mu \mathrm{M}$ the CCPR was reduced from $4 \cdot 96-2 \cdot 15$ cells/crypt/hour, at $10 \mathrm{nM}$ it was reduced from $4 \cdot 71-2 \cdot 10$ cells/crypt/hour, and at $100 \mathrm{pM}$ it was reduced from $4 \cdot 86-2.67$ cells/crypt/hour. The data showed a dose-response trend when individual results were compared with their own paired controls (as opposed to the overall control values), percentage reductions being $57 \%, 55 \%$, and $45 \%$ with diminishing doses of $1,25(\mathrm{OH})_{2}$ $\mathrm{D}_{3} \quad(57 \%$ v $45 \%$ : $\mathrm{p}<0.05)$. Ergocalciferol (vitamin $\mathrm{D}_{2}$ ) at a dose of $10 \mathrm{nM}$ reduced CCPR in the normal rectal tissue from $5 \cdot 27-2 \cdot 74$ cells/ crypt/hour. Calcipotriol $\left(10^{-7} \mathrm{M}\right)$ also reduced 


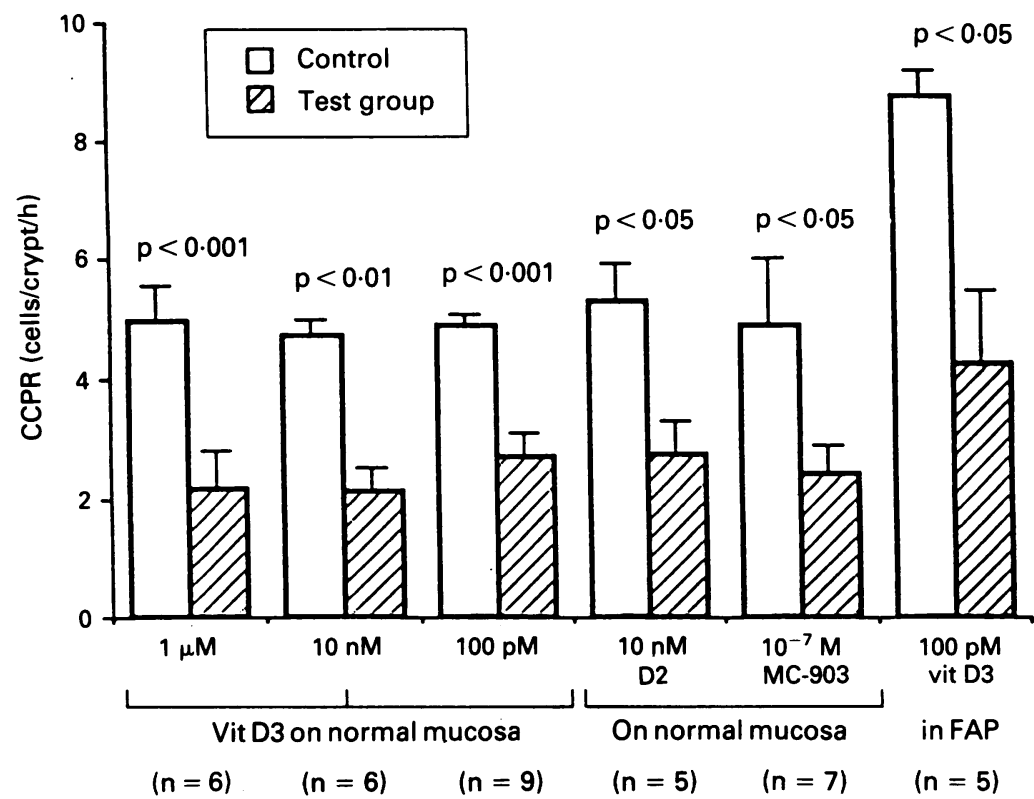

Effect of vitamin D on the crypt cell production rate $(C C P R)$ in human rectal tissue. Values are mean $(S E M)$. crypt/hour.

In patients with familial adenomatous poly- the CCPR in seven patients from $4 \cdot 86-2 \cdot 38$ cells/ posis, the baseline CCPR seemed to be higher than the overall control value $(8.75 v 4.74$ cells crypt/hour) but the difference did not reach statistical significance. Again, 1,25 $(\mathrm{OH})_{2} \mathrm{D}_{3}$ halved the CCPR from 8.75-4.22 cells/crypt/ hour (Figure).

\section{IMMUNOHISTOCHEMISTRY}

The active metabolite, $1,25(\mathrm{OH})_{2} \mathrm{D}_{3}$ reduced the crypt labelling index (measured using Ki-67) from a control value of $7 \cdot 28(0.68)$ (mean (SEM)) to $3.74(0.64)(\mathrm{n}=4, \mathrm{p}<0.01$, paired Student's $t$ test)

\section{CELL CULTURE}

HT-29 cells in control media showed a rapid log phase growth in the first 14 days of culture. Thereafter cells continued to proliferate but at a diminished rate (possibly because of cell to cell contact). After 21 days' culture there were $8.29(0.74) \times 10^{6}$ cells in control cultures (mean (SEM)). Calcipotriol produced a clearcut dose dependent inhibition of proliferation. After 21 days' culture calcipotriol reduced the number of cells to $0.06 \%$ of the control value at $10^{-5} \mathrm{M}(\mathrm{p}<0.01)$, to $0 \cdot 11 \%$ at $10^{-6} \mathrm{M}$ $(\mathrm{p}<0.01)$, to $8.45 \%$ at $10^{-7} \mathrm{M}(\mathrm{p}<0.001)$, and to $94 \cdot 10 \%$ at $10^{-8} \mathrm{M}$ (see Table).

\section{Discussion}

We have shown for the first time an inhibition of

The effect of calcipotriol on HT-29 cell growth. Values are total cell numbers (mean (SEM))

\begin{tabular}{|c|c|c|c|}
\hline $\begin{array}{l}\text { Concentration } \\
\text { of calcipotriol } \\
(M)\end{array}$ & Day 7 & Day 14 & Day 21 \\
\hline $\begin{array}{l}\text { Control } \\
1 \times 10^{-5} \\
1 \times 10^{-6} \\
1 \times 10^{-7} \\
1 \times 10^{-8} \\
1 \times 10^{-9}\end{array}$ & $\begin{array}{l}12 \cdot 84(0 \cdot 88) \times 10^{5} \\
3.34(1 \cdot 09) \times 10^{4 \star \star} \\
6 \cdot 40(1 \cdot 00) \times 10^{4 \star \star} \\
1.97(0 \cdot 73) \times 10^{5 \star \star \star} \\
4 \cdot 50(0 \cdot 23) \times 10^{5 \star} \\
8 \cdot 00(0.41) \times 10^{5 \star}\end{array}$ & $\begin{array}{c}64 \cdot 75(3.97) \times 10^{5} \\
4.40(0.53) \times 10^{3 \star \star} \\
10.90(3.48) \times 10^{4 \star \star} \\
4.44(1.80) \times 10^{5 \star \star \star} \\
48 \cdot 70(1.44) \times 10^{5 \star} \\
45.00(0.81) \times 10^{5 \star}\end{array}$ & $\begin{aligned} 82.92(1.45) & \times 10^{5} \\
4.70(1.37) & \times 10^{3 \star \star} \\
9.00(1.50) \times 10^{3 \star \star} & 10 \\
7.01(2.92) \times 10^{5 \star \star \star} & 10 \\
78.00(2.49) & \times 10^{5} \\
110.00(0.01) & \times 10^{5}\end{aligned}$ \\
\hline
\end{tabular}

Significance $v$ control (analysis of variance): ${ }^{\star} \mathrm{p}<0.05 ;{ }^{\star \star} \mathrm{p}<0.01 ;{ }^{\star \star \star} \mathrm{p}<0.0001$. in vitro CCPR in normal and premalignant human rectal epithelium by vitamin $\mathrm{D}$ and its metabolites. The data have been verified immunohistochemically using the monoclonal antibody $\mathrm{Ki}-67$ to show a reduction in the labelling index. The presence of vitamin $\mathrm{D}_{3}$ receptors in normal and malignant colorectal tissue, ${ }^{19}$ together with the increased colonic absorption of calcium after small bowel resection, ${ }^{29}$ had previously suggested that the colon could be a target organ for $1,25(\mathrm{OH})_{2} \mathrm{D}_{3}$. We have now shown an in vitro physiological response in colorectal tissue to the active metabolite of vitamin $\mathrm{D}_{3}$ and related compounds.

The dose dependent inhibition of HT-29 cell growth by calcipotriol (MC-903) correlates well with reports of the responsiveness of this cell line to $1,25(\mathrm{OH})_{2} \quad \mathrm{D}_{3} \cdot{ }^{17}{ }^{18}$ Calcipotriol has limited effects on calcium metabolism, while it retains potent cell regulatory properties. ${ }^{20-23}$ Clinical trials using calcipotriol suggest that it is a safe and effective topical treatment for psoriasis vulgaris. ${ }^{23}$ Our data suggest that it also has an effect on colorectal tissue.

There is now substantial evidence to show that $1,25(\mathrm{OH})_{2} \quad \mathrm{D}_{3}$ acts as a differentiating agent $^{15-183031}$ and that some of these actions are associated with a modulation of receptor concentrations. ${ }^{3132}$ Differentiating cells have in some cases shown a reduction in vitamin $\mathrm{D}$ receptor expression (for example HT-29 cells), ${ }^{7}$ and the modulation of receptor expression may be dependent on the state of differentiation. Although our observations could reflect a receptor associated genomic effect, to establish the fact would require correlation with changes in a measurable gene product. ${ }^{1+}$ The almost equal inhibition of CCPR by ergocalciferol compared with the active metabolite $\left(1,25(\mathrm{OH})_{2} \quad \mathrm{D}_{3}\right)$ argues against a receptor mediated effect, since non-hydroxylated vitamin $\mathrm{D}_{2}$ binds poorly to the vitamin $D$ receptor.

An alternative hypothesis is that our observed effect on proliferation may be a non-genomic effect, possibly related to calcium ion transport (as suggested by the presence of cytosolic calcium binding proteins in the colonic mucosa of short bowel syndrome) $)^{34}$ or to a post-receptor binding effect. ${ }^{20}$ In support of this, both verapamil and glucocorticoids (which influence calcium transport) affect the morphological changes induced by $1,25(\mathrm{OH})_{2} \mathrm{D}_{3}$ in LOVO cells. ${ }^{1+}$

Irrespective of the mode of action, vitamin D, its metabolites and analogues inhibit colonic epithelial proliferation, at least in vitro. In premalignant conditions associated with an accelerated epithelial cell proliferation, a reduction in CCPR might be beneficial. Further studies to evaluate the mode of action and possible therapeutic use of vitamin $\mathrm{D}$ metabolites and analogues are obviously required.

The authors thank Dr Lise Binderup from Leo Pharmaceuticals, who provided us with the secosterol Calcipotriol (MC 903) Financial assistance for this work was provided by the Nutritional consultative Panel.

1 Lipkin M. Biomarkers of increased susceptability to gastrointestinal cancer: new applications of studies of cancer prevention in human subjects. Cancer Res 1988; 48: 235-45.

2 Rainey JB, Davies PW, Willamson RCN. Relative effects of ileal resection and bypass on intestinal adaptation and carcinogenesis. Br.f Surg 1984; 71: 197-202. 
3 Williamson RCN, Bauer FLR, Ross JS, Watkins JB, Malt RR. Enhanced colonic carcinogenesis with azoxymethane in rats after pancreatobiliary diversion to mid small bowel. rats after pancreatobiliary diversion
Gastroenterology 1976; 76: 1386-92.

4 Reddy BS, Maeura Y. Tumour promotion by dietary fat in azoxymethane-induced colon carcinogenesis in female F344 rats: influence of amount and source of dietary fat. $7 \mathrm{NCL}$ 1984; 72: 745-50.

5 Rainey JB, Davies PW, Bristol JB, Williamson RCN. Adaptation and carcinogenesis in defunctioned rat colon: divergent effects of faeces and bile acids. Br $\mathcal{F}$ Cancer 1983; 48: 477-84.

6 Terpstra OT, Dahl EP, Williamson RCN, Ross JS, Malt RA. Colostomy closure promotes cell proliferation and dimethylhydrazine-induced carcinogenesis in rat distal colon. Gastroenterology 1981; 81: 475-80.

7 Terpstra OT, Van Blankstein M, Dees J, Eilers GAM. Abnormal pattern of cell proliferation in the entire colonic mucosa of patients with colon adenoma or cancer. Gastroenterology 1987; 92: 704-8.

8 Allan A, Bristol JB, Williamson RCN. Crypt cell production rate in ulcerative proctocolitis: differential increments in remission and relapse. Gut 1985; 26: 999-1003.

9 Wright NA, Appleton DR. The metaphase arrest technique a critical review. Cell Tissue Kinet 1980; 13: 643-63.

10 Wright NA, Goodlod RA. Measurement of cell proliferation. Gastroenterology 1986; 1: 216-7.

11 Appleton GVN, Davies PW, Bristol JB, Williamson RCN. Inhibition of intestinal carcinogenesis by dietary supplemenInhibition of intestinal carcinogenesis by dietary

12 Appleton GVN, Bristol JB, Williamson RCN. Increased dietary calcium and small bowel resection have opposite effects on colonic cell turnover. $\operatorname{Br} \mathcal{F}$ Surg 1986; 73: 101821.

13 Garland C, Barrett-Connor ER, Shekelle RB, Crique MM, Paul O. Dietary vitamin D and calcium and risk of colorectal cancer. Lancet 1985; i: 307-9.

14 Lointier P, Wargovich MI, Saez S, Levin B, Wildrick DM, Boman BM. The role of vitamin $D_{3}$ in the proliferation of a human colon cancer cell line lovo in-vitro. Anticancer Res 1987; 7: 817-22.

15 Tanakar M, Abe E, Miyaura C, Shina Y, Suda T. 1,25dihydroxy vitamin $\mathrm{D}_{3}$ induces differentiation of human
promyelocytic leukaemic cell $\mathrm{HL}-60$ into monocytepromyelocytic leukaemic cell HL-60 into monocyte-
macrophage but not granulocytes. Biochem Biophy Res macrophage but not gran

16 Colston KW, Berger U, Coombes RC. Possible role of vitamin $\mathrm{D}$ in controlling breast cancer proliferation. L ancet 1989; 38: 188-91.

17 Brehier A, Thomasset M. Human colon cell line HT-29 characterisation of 1,25 dihydroxy vitamin $D_{3}$ receptor and induction of differentiation by the hormone. 7 Steroid Biochem 1988; 29: 265-70.

18 Harper KD, Iozzo RV, Haddard JG. Receptors for and bioresponses to 1,25 dihydroxyvitamin $\mathrm{D}$ in a human colon carcinoma cell line (HT-29). Metabolism 1989; 28: 1062-9.

19 Lointier P, Meggouh F, Dechelotte P, Pezet D, Ferrier Ch,
Chipponi J, et al. 1,25 dihydroxy vitamin $\mathrm{D}_{3}$ receptors and human colon adenocarcinoma. Br 7 Surg 1991; 78: 435-9.

20 Binderup L Latini S, Binderup E, Bretting C, Calverley M, Hansen K. 20-Epi-vitamin $D_{3}$ analogues: a novel class of potential regulators of cell growth and immune responses. Biochem Pharmacol 1991; 42: 1569-75.

21 Keragballe K, Beck H, Segaard H. Improvement of psoriasis by a topical vitamin $\mathrm{D}_{3}$ analogue (MC-903) in a double blind study. Br $\mathcal{F}$ Dermatol 1988; 119: 223-30.

22 Binderup L, Bramm E. Effects of a novel vitamin D analogue MC-903 on cell proliferation and differentiation in-vitro and on calcium metabolism in-vivo. Biochem Pharmacol 1988; 37: 889-95.

$23 \mathrm{Kragballe} \mathrm{K}$. Treatment of psoriasis by the application of the novel cholecalciferol analogue calcipotriol (MC 903). Arch Dermatol 1989; 125: 1647-52.

24 Appleton GVN, Wheeler EE, Al-Mufti R, Challacombe DN, Williamson RCN. Rectal hyperplasia after jejunoileal bypass for morbid obesity. Gut 1988; 29: 1544-8.

25 Fergusson A, Sutherland A, MacDonald TT, Allen F. Technique for microdissection and measurement in biopsies of human small intestine. $\mathcal{F}$ Clin Pathol 1977; 30: 1068-73.

26 Gerdes J, Schwab U, Lemeke H, Stein H. Production of a mouse monoclonal antibody reactive with a human nuclear antigen associated with cell proliferation. Int $\mathcal{f}$ Cancer 1983; 31: 13-20.

27 Gerdes J, Lemeke H, Baisch H, Wacker HH, Schwab U, Stein H. Cell cycle analysis of a cell proliferation-associated human nuclear antigen defined by the monoclonal antibody Ki-67. F Immunol 1984; 133: 1710-5.

28 Franklin WA, McDonald GB, Stein HO, Gatter KC, Jewell $\mathrm{DP}$, Clarke LC, et al. Immunohistological demonstration of abnormal colonic crypt kinetics in ulcerative colitis. Human Pathol 1985; 16: 1129-32.

29 Hylander $\mathrm{E}$, Ladefoged $\mathrm{K}$, Jarnum $\mathrm{S}$. The importance of the colon in calcium absorption following small intestinal resection. Scand f Gastroenterol 1980; 15: 55-60.

30 Studzinski GP, Bhandal AK, Brelvi ZS. Cell cycle sensitivity of HL-60 cells to the differentiation-inducing effects of 1,25 dihydroxy vitamin $D_{3}$. Cancer Res 1985; 45: 3898-905.

31 Bhalla AK, Amento EP, Clemens TL, Holick MF, Krane SM. Specific high affinity receptors for 1,25 dihydroxy vitamin $\mathrm{D}_{3}$ in human peripheral blood mononuclear cells: presence $\mathrm{D}_{3}$ in human peripheral blood mononuclear cells: presence in monocytes and induction in T-lymphocytes

32 Provvedini DM, Deftos LJ, Manolagos SC. 1,25 dihydroxy vitamin $D_{3}$ receptors in a subset of mitotically active lymphocytes from rat thymus. Biochem Biophys Res Commun 1984; $121: 277$.

33 Magnelsodorf DJ, Koeffher HP, Donaldson CA, Pike JW, Haussler MR. 1,25 dihydroxyvitamin $\mathrm{D}_{3}$-induced differentiation in a human promyelocytic leukaemia cell line (HL60): receptor-mediated maturation to macrophage-like cells. 7 Cell Biol 1984; 98: 391 .

34 Staun M. Distribution of the 10000 molecular weight calcium binding protein along the small and large intestine of man. Gut 1987; 28: 878-82. 